\title{
Peran TPA dalam Penyelenggaraan Pendidikan Al-Qur'an di Masjid Al-Fattah Palembang
}

\author{
Dedi Setiawan \\ STIT Misbahul Ulum Gumawang \\ Belitang Ogan Komering Ulu (OKU) Timur-Sumsel \\ Email: dedi.setiawan7686@yahoo.com \\ Amir Rusdi \\ Fakultas Ilmu Tarbiyah dan Keguruan \\ Universitas Islam Negeri Raden Fatah Palembang \\ Email: amirrusdi@radenfatah.ac.id \\ Vinny Aisyahlani Putri \\ Alumni PGMI FITK \\ Universitas Islam Negeri Raden Fatah Palembang \\ Email: vinny@gmail.com
}

\begin{abstract}
Mentioning the Qur'an to children since childhood is easier than to teach the Qur'an as an adult.At this time, children have greater potential to learn and remember lessons. Quran Education Park (TPA) is a non-formal education institution that seeks to educate children from 7-12 years of age or elementary school age, so as to read, understand and practice the Qur'an. This research using qualitative descriptive approach. This research emphasizes on the role of education education of Al-Qur'an Quran Education Park (TPA). The population in this study as many as 6 teachers consisting of 1 male, 5 female and 31 students consisting of 17 men, 14 women. To obtain data author using observation data, interviews, test and documentation. Observation is to observe learning activity of Al-Qur'an Education Park (TPA), interview with santri guardian that is to know have been achieved the purpose of a educationin in Quran Education Park (TPA) and Tests to further prove from result of interview Done with students guardian. From the analysis, it can be concluded that from the 6 main objectives of the teaching of Al-Qur'an Education Park (TPA) can be said to play a good role in the education of AlQur'an as well as Wirutomo argued that David Berry's opinion was defined as a set of expectations To individuals who occupy certain social positions. From the opinion of David Berry it is clear that after doing the research of Al-Qur'an Mosque of Al-Qur'an (TPA) Al-Fattah Mosque has reached the desired expectations in accordance with the purpose of teaching the Education of Al-Qur'an (TPA).
\end{abstract}

Abstrak: Mangajarkan Al-Qur'an kepada anak sejak kecil lebih mudah dari pada mengjarakan Al-Qur'an ketika dewasa. Pada masa ini, anak memiliki potensi yang lebih besar untuk belajar serta mengingat pelajaran. Taman Pendidikan Al-Qur'an (TPA) adalah suatu lembaga pendidikan non formal yang berupaya mendidik anak-anak dari usia 7-12 tahun atau usia masuk Sekolah Dasar, sehingga mampu membaca, memahami dan mengamalkan Al-Qur'an.

Penelitian ini lapangan dengan menggunakan pendekatan deskriptif kualitatif. Penelitian ini menekankan pada peran dslsm pendidikan Al-Qur'an Taman Pendidikan Al-Qur'an (TPA). Adapun populasi dalam penelitian ini sebanyak 6 guru yaitu terdiri dari 1 laki-laki, 5 perempuan dan 31 santri yang terdiri dari 17 laki-laki, 14 perempuan. Untuk memperoleh data penulis mengunakan data observasi, wawancara, test dan dokumentasi. Observasi yaitu untuk mengamati aktivitas pembelajaran Taman Pendidikan Al-Qur'an (TPA), wawancara dengan 
wali santri yaitu untuk mengetahui sudah tercapai kan tujuan suatu pengajran di Taman Pendidikan Al-Qur'an (TPA) dan Tes untuk lebih membuktikan dari hasil wawancara yang dilakukan dengan wali santri. Dari analisi tersebut maka diperoleh kesimpulan yaitu: dari 6 pokok tujuan penagajaran Taman Pendidikan Al-Qur'an (TPA) sudah bisa dikatakan berperan baik dalam pendidikan Al-Qur'an seperti halnya Wirutomo mengemukakan pendapat David Berry perana itu didefinisikan sebagai seperangkat harapan yang dikenankan kepada individu yang menempati kedudukan sosial tertentu. Dari pendapat David Berry ini jelas bahwa setelah dilakukannya penelitian Taman Pendidiakn Al-Qur'an (TPA) Masjid Al-Fattah ini sudah mencapai harapan-harapan yang diinginkan sesuai dengan tujuan pengajaran Taman Pendidikan Al-Qur'an (TPA).

Kata Kunci: TPA, penyelenggaraan pendidikan Al-qur'an

\section{A. Pendahuluan}

Pendidikan adalah salah satu kebutuhan yang penting dan mendasar bagi kebahagiaan hidup manusia. Karena pendidikan akan membuat kehidupan manusia menjadi maju dan berkembang. Pendidikan merupakan proses perkembangan individu yang dilakukan secara sadar agar menjadi manusia dewasa dan bertanggung jawab yang berlangsung seumur hidup. Hal ini sejalan dengan tujuan pendidikan nasional yang berisi: "Pendidikan Nasional bertujuan mencerdaskan kehidupan bangsa dan mengembangkan manusia Indonesia seutuhnya yaitu manusia yang beriman dan bertaqwa terhadap Tuhan Yang Maha Esa dan berbudi pekerti luhur, memiliki pengetahuan dan keterampilan, kesehatan jasmani dan rohani, kepribadian mantap dan mandiri sera rasa tangung jawab kemasyarakatan dan kenegaraan" (Hasan, 1997, hal. 1).

Pendidikan yang pertama terletak pada lingkungan keluarga. Dalam hal ini, kedua orang tua sebagai pendidik utama bagi anak mempunyai tangung jawab yang besar untuk menjaga dan mendidik anak-anak mereka. Anak adalah amanah dari Allah SWT. Tidak semua orang mendapatkan anugerah ini, kecuali orang-orang yang dikehendakiNya. Orang tua sudah sepatutnya menerima amanah tersebut dengan penuh tangug jawab. Perintah Allah tersebut menunjukkan bahwa setiap orang tua wajib mendidik dan memelihara anak-anak mereka dengan sebaik-baiknya.

Allah SWT memerintahkan orang-orang beriman untuk mendidik diri dan keluarga mereka dengan perbuat baik. Orang tua wajib memberikan pendidikan yang baik terutama pendidikan islam sehingga akan terbentuklah sebuah keluarga yang islami, dengan demikian akan mendorong terbentuknya masyarakat islam.

Pendidikan Islam adalah salah satu usaha orang dewasa muslim yang bertaqwa secara sadar mengerahkan dan membimbing pertumbuhan serta perkembangan fitrah (Kemampuan dasar) anak didik melalui ajaran islam kearah titik maksimal pertumbuhan dan perkembangannya (Arifin, 2003. Hal. 22).

Orang tua mempunyai peranan yang sangat besar untuk mendidik, membentuk dan menata pribadi anak-anak mereka dengan pendidikan islam melalui penanaman nilai-nilai ajaran islam dan akhlak. Dalam islam kewajiban orang tua yang utama adalah 
mengajarakan Al-Qur'an kepada anak-anaknya. Mengajarkan Al-Qur'an adalah salah satu dasar pendidikan islam, berdosalah bagi orang tua yang mempunyai anak tetapi anak-anaknya tidak pandai membaca Al-Qur'an dan menjaga akhlaknya. Al-Qur'an adalah kalam Allah yang diturunkan kepada Nabi Muhammad SAW untuk diajarkan kepada umat manusia di seluruh dunia. Di dalamnya terdapat petunjuk dan pedoman itu, manusia akan bahagia hidup didunia maupun di akhirat kelak.

Al-Qur'an adalah petunjuk dan kebenaran yang nyata. Mempelajari Al-Qur'an baik bacaan, tulisan, maupun isi yang terkandung di dalamnya adalah kewajiban bagi kaum muslimin. Hendaknya Al-Qur'an sudah harus diajarkan orang tua kepada anak sejak usia anak-anak. Pada usia ini, anak lebih mudah menyimak dan memiliki potensi belajar yang benar dan sangat kuat, sehingga para ahli pendidikan menyebutnya dengan masa peka untuk belajar (Jalaluddin, 1989, hal. 2).

Mengajarkan Al-Qur'an kepada anak sejak kecil lebih mudah dari pada mengajarkan Al-Qur'an ketika telah dewasa. Pada masa ini, anak memliki potensi yang lebih besar untuk belajar serta mengingat pelajaran. Sehingga pelajaran yang ia terima akan mudah melekat dan tidak mudah hilang.

Selain pendidikan yang diberikan orang tua dalam lingkungan keluarga, anak juga membutuhkan pendidikan dari luar seperti lembaga pendidikan islam nonformal yang terletak dalam lingkungan masyarakat. Pendidikan ini mencakup penyelamatan fitrah islamiyah anak, perkembangan potensi fikir anak, potensi kerja, dan sebagainya karena tidak semua orang tua mampu menangani pendidikan anaknya secara keselurahan, mengingat berbagai keterbatasan yang dimiliki orang tua, misalnya keterbatasan waktu, keterbatasan ilmu pengetahuan dan keterbatasan lainnya. Oleh karena itu orang tua dapat menyerakan pendidikan anaknya pada Taman Pendidikan Al-Qur'an (TPA).

Agar umat islam yang buta aksara Al-qur'an tidak semakin betambah maka pendidikan TPA ini adalah pilihan tepat untuk mencegah hal tersebut. Jadi dengan diselenggarakannya TPA (Taman Pendidikan Al-Qur'an) sebagai lembaga pendidikan Islam non Formal di lingkungan masyarakat dapat membantu peluang kepada orang tua untuk mendidik anak-anaknya mengikuti dan mendalami pendidikan islam. TPA memegang peranan penting untuk penyiapan generasi penerus sebagai pengusung pembangunan dan masa depan bangsa. Jenis pendidikan ini merupakan salah satu bentuk jalur pendidikan agama yang diorientasikan untuk meningkatkan taraf pengetahuan terhadap Islam khususnya keagamaan baca tulis dan pengamalan AlQur'an dan kemapuan membaca Al-Quran.

Taman pendidikan Al-Qur'an (TPA) adalah suatu lembaga atau sekolah yang berupaya mendidik anak-anak dari usia 7-12 tahun atau usia masuk Sekolah Dasar. Sehingga mampu membaca, memahami dan mengamalkan Al-Qur'an. Adapun tujuan pendidikan di TPA adalah:

1. Membantu mengembangkan potensi anak kearah pembentukan sikap, pengetahuan dan keterampilan keagamaan melalui pendekatan yang disesuaikan dengan lingkungan dan taraf perkembangan anak, berdasarkan tuntutan Al-Qur'an dan sunnah Rasulullah. 
2. Mempersiapkan anak agar mampu mengembangkan sikap, pengetahuan, dan keterampilan keagamanan yang telah dimiliki melalui program lanjutannya.

Sedangkan tujuan pengajaran di TPA adalah:

1. Santri dapat memahami Al-Qur'an sebagai bacaan dan pedoman

2. Santri dapat membaca Al-Qur'an dengan benar dan lancar.

3. Santri dapat mengerjakan shalat 5 waktu dengan tata cara yang benar.

4. Santri dapat menguasai hafalan sejumlah surat pendek (ayat pilihan untuk TPA) dan doa sehari-hari.

5. Santri dapat berakhlak sosial yang baik sesuai dengan tuntutan Islam.

6. Santri dapat menulis huruf Arab dengan baik dan benar (Syarmudin, 2006), hal. 8).

Adapun objek dari penelitian ini adalah Taman Pendidikan Al-Qur'an (TPA) di Masjid Al-Fattah yang teletak di jalan Halim Batubara Sekip Ujung Palembang. Pendidikan Al-Qur'an di TPA ini tidak terlepas dari adanya berbgai faktor pendukung dan penghambat yang bisa menjadi problematika dalam penyelenggaraan TPA.

Berkaitan dengan pendidikan Al-Qur'an di TPA Masjid Al-Fattah, faktor pendukung dan penghambat, anatara lain:

1. Faktor Internal (dari dalam) meliputi kompetensi pengajar, menguasai materi apa saja yang akan di sampaikan dalam pembelajaran, kemampuan memahami karakter siswa, kemampuan melaksanakan proses pengajaran, kemampuan mengukur atau mengeveluasi hasil belajar siswa, kemampuan menggunakan media pembelajaran, kemampuan mengunakan metode pembelajaran, memahami kurikulum yang digunakan, mengolah kelas belajar, kesehatan pengajar, dan kesejahteraan pengajar.

2. Faktor Eksternal (dari luar) adalah faktor yang berasal dari luar diri pengajar, seperti memberi fasilitas pencapaian tujuan melalui pengalaman belajar yang memadai, sarana dan prasarana sekolah yang memadai, kurangnya media pembelajaran di TPA dan minat belajar santri dan santriwati.

Faktor-faktor tersebut, jika terpenuhi atau tersedia di TPA Masjid Al- Fatah, maka tentu menjadi faktor pendukung. Namun, sebaliknya apabila faktor tersebut tidak ada atau tidak tersedia, maka akan menjadi faktor penghambat atau problem dalam penyelenggaraan pendidikan Al-Qur'an di TPA Masjid Al-Fattah Sekip Ujung Palembang.

Dari penjelasan di atas, dapat diketahui bahwa begitu besar peran TPA dalam dalam mengurangi buta baca Al-Qur'an pada anak-anak. Diharapkan melalui TPA ini anak-anak mampu memulai belajar dan membaca Al-Qur'an sejak dini. Untuk itu penulis tertarik mengetahui lebih lanjut mengenai “ Peran Taman Pendidikan Al-Qur'an (TPA) dalam Penyelenggaraan Pendidikan Agama di Masjid Al-Fattah Sekip Ujung Palembang."

Berdasarkan latar belakang masalah diatas, maka permasalahan penelitian dapat diidentifikasikan sebagai berikut : Berdirinya TPA sebagai lembaga pendidiakn Islam yang mempunyai banyak peran penting bagi perkembangan anak dalam 
Penyelenggaraannya mengalami permasalahan seperti keterbatasan tenaga pengajar, saran administrasi yang sederhana, lemahnya minat orangtua untuk memasukkan anaknya ke TPA dengan alasan bahwa TPA tidak penting, lemahnya minat belajar dari santri, TPA dianggap tidak penting dibanding lembaga nonformal lainnya misalnya bimbel, sekolah khusus bahasa inggris dll, maupun masalah keuangan. Permasalahan keuangan ini merupakan permasalahan yang sering muncul kepermukaan, contonya masih adanya keterlambatan pembayaran uang spp dalam setiap bulannya. Permasalahan lain yang ada di TPA adalah masih sederhananya cara pengelolaan TPA yang hanya sesuian dengan situasi dan kondisi yang ada.

Dengan adanya berbagai permasalahan yang dihadapi oleh TPA Masjid Al-Fattah Sekip Ujung Palembang sudah tentu menjadi kendala TPA dalam menjalannkan peranya. Oleh karena itu keberhasilan TPA memerlukan kesadaran, dukungan dan kerjasama dari berbgai pihak yaitu pihak TPA, orang tua anak (santri), dan masyarakat.

Berdasarkan latar belakang permasalahan diatas, maka dapat dirumuskan permasalahan sebagai berikut: Bagaimana peran Taman Pendidikan Al-Qur'an (TPA) dalam Penyelenggaraan pendidikan Al-Qur'an Masjid Al-Fattah Sekip Ujung Palembang?

Adapun tujuan dari penelitian ini adalah: Untuk mengetahui peranan dari Taman Pendidikan Al-Qur'an (TPA) Masjid Al-Fattah Sekip Ujung Palembang dalam Penyelenggaraan Pendidikan Al-Qur'an.

\section{B. Kajian Literatur}

TPA sebagai lembaga pendidikan nonformal yang mempunyai peran utama mengajarkan kemampuan membaca dan menulis Al-Qur'an juga sangat berperan bagi perkembangan jiwa anak seperti pengetahuan tentang ibadah, akidah, dan akhlak. Mengingat bahwa materi yang diajarkan tidak hanya terpaku pada materi baca tulis AlQur'an melainkan juga memberikan materi tentang ibadah, aqidah, akhlak atau akhlak yang bertujuan mempersiapkan peserta didik menjadi pribadi yang Qur'ani dan menjadikan Al-Qur'an sebagai pedoman dalam hidupnya.

Penyelenggaraan pendidikan Al-Qur'an adalah suatu proses belajar mengajar dengan membaca, menulis, menghafal, menterjemahkan kata atau kalimat dengan berpedoman kepada Al-Qur'an (Anwar, 2000, hal. 31). Sedangkan pendidikan berasal dari kata "didik" dengan berawalan "pe" dan akhiran "an" mengandung arti "perbuatan" dilihat dari bahasa Yunani, yaitu "paedagogie" yang bearti bimbingan yang diberikan kepada anak dalam baga inggris yang disebut "education" yang berarti pengembangan atau bimbingan dalam bahasa arab disebut "tarbiyah" yang bearti pendidikan (Arifin, 2000, hal. 23).

Al-Qur'an yang merupakan kalam Allah yang merupakan mukjizat yang diturunkan (diwahyukan) kepada Nabi Muhammad SAW, dan yang ditulis di mazhab serta diriwayatkan dengan mutawir dan membacanya adalah ibadah (Hamiri, 2008, hal. 2). Selanjutnya Al-Qur'an berasal dari kata "Qara'ah" yang berbentuk "masdar" dengan arti isi maf'ul yaitu "maqru" (dibaca). 
Berkaitan dengan pendidikan, dalam proses pembelajaran terhadap dua unsur inti, yaitu belajar dan pengajar. Belajar adalah orang yang menuntut ilmu sedangkan pengajar adalah orang yang memberikan ilmu pengetahuannya kepada orang lain. Belajar adalah perubahan diri seseorang, dimana perubahan itu dapat diwujudkan dalam bentuk pengertian, kecakapan, sikap, dan kebiasaan, setelah seseorang melakukan belajar, ia merasa lebih pandai, lebih mengerti, semangat dan lainnya (Djalali, 2013, hal. 61).

Pendidikan agama yang dilaksanakan orang tua sebelum anak masuk sekolah terjadi secara tidak formal, pendidikan agama pada umur ini melalui semua pengalaman anak, baik melalui ucapan yang didengar, tindakan perbutan dan sikap yang dilihatnya maupun perilaku yang dirasakannya, oleh karena itu keadaan orang tua dalam kehidupan mereka mampunyai pengaruh yang sangat besar dalam pembinaan kepribadian anak, dan para ahli jiwa menganggap bahwa dalam segala hal anak merupakan peniru yang sangat baik (Ramayulis, 2005, hal. 182).

Orang tua wajib mengajarkan membaca menulis Al-Qur'an kepada anak-anaknya, atau kakak kepada adik-adiknya maupun memanggil guru untuk membaca dan menulis Al-Qur'an, atau ustadz kerumah untuk mengajarnya, karena setelah anak berumur 4-5 tahun didalam masyarakat juga sudah terdapat pengajian-pengajian baik di masjid maupun ditempat lain, seperti adanya Taman Pendidikan Al-Qur'an (TPA), Taman Kanak-kanak Al-Qur'an (TKA), maupun Taman Pendidikan Qur'an (TPA) (Nuryanis, 2003, hal. 42).

Jelas bahwa Allah SWT memerintahkan kepada setiap orang muslim untuk mendidik, menjaga, dan memelihara anak-anak mereka dengan baik. Orang tua wajib memberikan pendidikan yang baik terutama pendidikan Islam, misalnya memasukkan anak-anak mereka di lembaga pendidikan Islam nonformal di lingkungan masyarakat seperti TPA. Sehingga dengan demikian akan bertambah sebuah keluarga Islami yang akan mendorong terbentuknya masyarakat Islami. Begitu penting pendidikan Islam yang harus diberikan oleh orang tua bagi anak-anak sejak dini agar kelak mereka tidak hanya bisa membaca Al-Qur'an tetapi juga menjadi anak yang soleh dan solehah serta menaati perintah-perintah Allah dan menjauhi larangan-Nya.

Langkah-langkah Penyelenggaraan Pendidikan Al-Qur'an, maka TPA menggunakan langkah-langkah sebagai berikut meliputi klasika I, privat dan klasika II sebagai berikut:

1. Klasika I, Doa, pembukaan, ikrar santri dan hymne TPA, penyampaian materi

2. Privat, setiap ustadz/ustadzah membimbing santri membaca Al- Qur'an/Iqra sesuai tingkatan/ jilid masing-masing. Setiap santri diberi waktu $10 \mathrm{Menit}$

3. Klasika II, Satelah cara belajar privat selesai, seluruh santri mengulang materi klasika I, setelah itu membaca doa penutup dan pulang (Syarmudin, 2006, 24).

Selanjutnya, langkah lain dalam Penyelenggaraan pendidikan Al-Qur'an di TPA adalah dengan menerapkan metode Iqra, yang terdiri dari beberapa rangkaian kegiatan seperti baca Iqra', hapalan surat pendek, latihan membaca tadarus bittaril, hapalan ayat- 
ayat pilihan, hapalan bacaan shalat fardu, latihan praktek shalat, ilmu tajwid, latihan menulis Al-Qur'an, dan menulis kaligrafi (Depag Sumsel, 2005, hal. 17).

Dapat dipahami bahwa proses pelaksanaaan pendidikan Al-Qur'an merupakan rangkaian pedoman dan metode baca tulis Al-Qur'an yang diajarkan kepada anak-anak usia dini. Dengan harapan. Anak-anak kelak dapat membaca dan menulis Al-Qur'an sebagai modal dasar memahami Islam.

\section{Metode Penelitian}

Penelitian ini menggunakan pendekatan diskriptif kualitatif. Jenis yang digunakan dalam penelitian ini adalah penelitian lapangan. Dalam hal ini, penelitian berangkat ke "observasi lapangan" untuk mengadakan pengamatan tentang suatu fenomena dalam suatu keadaan alamiah (Depag Sumsel, 2005, hal. 17). Dalam penelitian ini, untuk mempermudah mengumpulkan data penulis mengunakan teknik pengumpulan yakni observasi, wawancara, dan dokumentasi. Sedangkan teknik analisis data, penulis mengunakan teknik analisis data yang dikemukanan oleh Mattew B. Milles dan A. Michael Huberman, yakni reduksi data, penyajian data dan verifikasi.

\section{Hasil dan Diskusi}

Berdasarkan hasil penelitian di lapangan, penulis menyajikan dalam bentuk uraian dan gambaran kata-kata secara tertulis. Adapaun hasil penelitian penulis mengenai hal-hal sebagai berikut:

\section{Peran TPA dalam Membantu Santri Mengagumi dan Mencintai Al-Qur'an}

Berkaitan dengan peran TPA dalam membantu santri mengagumi dan mencintai Al-Qur'an sebagai bacaan istimewa dan pendoman utama, penulis melakukan wawancara kepada wali santri seperti Masmelur, didapatkan hasil bahwa anak adalah titipan yang Allah berikan untuk kita jaga sebaik-baiknya. Orang tua harus membimbing anak dalam kebaikan. Saya sebagai orang tua sejak dini anak saya sudah saya ajarkan untuk mengenal agama yang saya anut, sejak dini saya kenalkan dengan Al-Qur'an. Ketika dia sudah semakin tumbuh, saya masukkan dia di TPA agar dia mendapat ilmu yang baik dari ustadz/ ustadzah karena ketika anak semakin tumbuh apabila kita masukkan di TPA dia akan mengingat apa yang telah diajarkan dan akan diikuti untuk kehidupannya. Dan ketika anak yang dimasukkan ke TPA ketika selesai shalat dia akan mengaji lagi kita sebagai orang tua tetap mendampingi anak membaca Al-Qur'an agar bukan hanya di TPA anak membacanya tetapi di setiap selesai shalat ia akan membacanya. Salah satu contohnya adalah anak saya menjadikan Ayat Kursi sebagai pedoman untuk menjaga dirinya (Wawancara Kepada Masmelus tanggal 06 Juni 2017).

Sedangkan menurut ibu Ike wali santri M.Novan Ade Syaputra mengatakan bahwa mengulangi pelajaran khusus pelajaran TPA, mengaji dan mengenalkan bacaan Al-Qur'an dilakukan pada anak sejak usia dini bahkan sejak usianya beranjak 1 tahun ketika anak masih di dalam kandungan pun sering didengarkan lantunan ayat-ayat AlQur'an ini adalah bentuk rasa cinta dan kagumnya terhadap Al-Qur'an maka dari itu 
penting sekali mengulangi pelajaran di sekolah maupun di tempat TPA saja namun di rumah juga baik ketika waktu luang atau setelah shalat sehingga kelak membuatnya terbiasa dan anak mengerti pentingnya belajar membaca Al-Qur'an.

Dari observasi penulis, memang benar bahawa santri menjadikan Al-Qur'an sebagai bacaan yang istimewa, seperti halnya saya mewawancarai salah satu santri yang bernama Mahase Ragil sekarang sudah mencapai batasan mengaji di juz 9 Mahesa mengatakan bahwa setiap selesai Maghrib dia selalu mengaji bersama ayahnya sehingga tidak hanya mempelajari Al-Qur'an di TPA saja dan inilah bentuk rasa cinta dan kangumnya terhadap Al-Qur'an (Wawancara Kepada Mahesa (Santri) tanggal 07 Juni 2017).

Akan tetapi Ibu Halimah wali dari santri yang bernama Rama Dani mengatakan bahawa anak saya sering tidak mengulang dalam pelajaran yang diajarkan di TPA,dan kurang dalam mengulang mengaji setelah sholat ataupun membaca Al-Quran di waktu kosong karena anak saya sering bermalas-malasan dalam melakukan hal-hal itu. Sedangkan Ibu santi mengatakan anak saya suka mengaji dirumah. Setelah sholat magrib dan shlat subuh. Dan juga anak saya selalu membaca surat Al-Ashr sebagai pengingat mereka untuk menjadi anak yang berperilaku disiplin akan waktu (Wawancara kepada Halima (Wali Santri) tanggal 06 Juni 2017).

Berdasarkan hasil wawancara bahwa siswa dapat mengagumi dan mencintai AlQur'an sebagai bacaan istimewa dan pedoman utama. Hal ini dibuktikan dengan adanya siswa membaca Al-Qur'an setiap selesai shalat fardhu. Dan mereka menjadikan ayat suci Al-Qur'an sebagai pedomannya seperti halnya mereka mereka senantiasa membaca ayat Kursi sebagai penjaga dirinya dan surat Al-Ashr sebagai pengingat mereka untuk menjadi anak yang berprilaku disiplin akan waktu. Sehingga dapat dikatakan bahwa Taman Pendidikan Al-Qur'an (TPA) Masjid Al-Fattah dalam penyelenggaran pendidikan Al-Qur'an berperan dengan baik dalam membantu siswa mengagumi dan mencintai Al-Qur'an sebagai bacaan istimewa dan pedoman utama.

\section{Paran TPA dalam Membimbing Santri Membaca Al-Qur'an dengan Baik dan Benar}

Dari hasil wawancara penulis dengan informan yaitu Ibu Masmelur wali santri Hania Nabila mengatakan bahwa saya adalah seorang ibu yang bercita-cita membesarkan anak dengan bekal ilmu agama. Saya sangat mengetahui perkembangan anak setiap hati ia semakin membaik untuk membaca Al-Qur'an karena setiap kali ia di TPA mendapatkan ilmu baru yang akan ia amalkan di dalam rumah. Jadi setiap kali ia pulang ia bercerita tentang bacaan mengajinya. Semakin baik dan setelah shalat ia langsung mengulanginya dan itu membuat saya bangga menjadi seorang ibu.

Sedangkan menurut Ibu Siti wali santri M. Rian Juliadi mengatakan bahwa setelah TPA Masjid Al-Fattah ada perbedaan yaitu dia mengaji lebih fasih, dan lebih mengerti panjang pendeknya suatu bacaan tersebut jadi saya sebagai seorang ibu tidak terlalu khawatir dengan anak saya kalau mereka tidak bisa mengaji. 
Pada tes kemampuan membaca Al-Qur'an tingkat dasar peneliti menggunakan surat Al-Baqarah ayat 6-10 para santri dipanggil satu persatu untuk membaca satu ayat dari 610 ayat yang telah disediakan dan dipilih oleh peneliti. Dalam hal ini peneliti menilai bahwa santri Masjid Al-Fattah ini rata-rata dari mereka sudah pandai membaca AlQur'an dengan kriteria tingkat dasar yaitu mampu membaca dengan lancar, baik, benar panjang pedek tanda baca dan jelas dalam penyebutan hurufnya. Dari hasil tes tersebut penulis mendapatkan hasil, untuk lebih jelas perhatikan pada tabel.

Tabel. 2

Hasil Tes Kemampuan Membaca Al-Qur'an Tingkat Dasar

\begin{tabular}{|l|l|l|l|}
\hline No & \multicolumn{1}{|c|}{ Nama } & Tahun Masuk & \multicolumn{1}{c|}{ Kelancran } \\
\hline 1 & Yusuf al-Qomar & 2011 & Lancar \\
\hline 2 & Hanniah Nabila & 2011 & Lancar \\
\hline 3 & Al-Farid & 2012 & Lancar \\
\hline 4 & Ramadhani & 2013 & Lancar \\
\hline 5 & M.Prayoga.S. & 2013 & Lancar \\
\hline 6 & M. Rian Juliandi & 2014 & Lancar \\
\hline 7 & Mahesa Ragil & 2014 & Lancar \\
\hline 8 & M. Novan Ade Saputra & 2015 & Lancar \\
\hline 9 & M. Bariq Al-Faiz & 2016 & Kurang Lancar \\
\hline 10 & Nasyirah Tiara Salima & 2016 & Kurang Lancar \\
\hline
\end{tabular}

Dalam hal ini peneliti membedakan santri yang sudah lama mengaji dan santri yang baru masuk sangat terasa sekali perbedaannya santri yang sudah mengaji dari tahun 2011 sudah sangat lancar dan tepat dalam pelafalan dan panjang pendek huruf, santri yang masuk tahun 2016 juga sudah bagus dalam membacanya akan tetapi hanya saja masih belum terlalu lancar dalam membacanya.

Berdasarkan hasil wawancara dan observasi di atas dapat dipahami bahwa santri Taman Pendidikan Al-Qur'an (TPA) Masjid Al-Fattah tesebut dapat membaca AlQur'an dengan benar dan lancar. Hal ini dibuktikan dengan terminimalisirnya siswa yang membaca Al-Qur'an dengan tertegun-tegun. Sehingga dapat dikatakan bahwa Taman Pendidikan Al-Qur'an (TPA) Masjid Al-Fattah dalam penyelenggaran pendidikan Al-Qur'an berperan dengan baik dalam membantu santri membaca AlQur'an dengan baik dan benar.

\section{TPA dalam Mengajarkan Shalat 5 Waktu}

Dari hasil wawancara penulis dengan Bapak Mardi wali santri M Al Farid mengatakan bahwa Semenjak anak saya belajar di TPA Masjid Al-Fattah Sekip Ujung Palembang, dia sudah berangsur mengerjakan sholat 5 waktu, walaupun masih sering bolong.

Sedangkan Ibu Masmelur mengatakan bahwa shalat adalah kewajiban seluruh umat Muslim. Anak akan mengikuti apa yang orang tuanya kerjakan. Saya sebagai 
orang tua harus memberikan contoh kepada anak ketika akan adzan tiba kita harus segera melakukan shalat tidak boleh menunda-nundanya. Anak terkadang ketika dia sedang asyik bermain akan menunda-nunda shalatnya, tetapi kita sebagai orang tua harus berusaha memberikan pemahaman yang baik kita ajak anak untuk melakukan shalat berjamaah. Dan ketika setelah ia TPA mendapatkan ilmu hingga saat ini ketika adzan dikumandangkan ia selalu tepat waktu mengerjakannya dengan tata cara yang benar meskipun belum sempurna karena saya pun memakluminya dia anak yang masih dalam tahap belajar.

Selain itu penulis juga melakukan observasi dengan melihat secara langsung para santri maju ke depan kelas satu persatu untuk tes hafalan dan praktek gerakan sholat yang benar.

Pendidikan di Taman Pendidikan Al-Qur'an (TPA) selain membimbing santri membaca dan menulis huruf-huruf hijaiyah Al-Qur'an, hapalan surat pendek Al-Qur'an, Taman Pendidikan Al-Qur'an (TPA) Masjid Al-Fattah Sekip Ujung Palembang juga membimbing santri belajar sholat 5 waktu atau sholat wajib. Menurut Ummi Nidar Selaku kepala unit TPA Sekip Ujung Masjid Al-Fattah satu minggu sekali mereka mengadakan sholat berjamaah di masjid. Setiap 6 bulan sekali mereka mengadakan evaluasi tata cara sholat yang benar yang akan menjadi tolak ukur di semester depannya.

Berdasarkan hasil wawancara dan observasi di atas, dapat dipahami bahwa santri dapat mengerjakan shalat lima waktu dengan tata cara yang benar. Walaupun masih terdapat siswa terdapat gerakan siswa yang belum sempurna, akan tetapi berangsurangsur menjadi lebih baik. Hal ini dibuktikan dengan diadakannya praktik santri mengerjakan shalat satu persatu dengan tata cara yang benar. Sehingga dapat dikatakan bahwa dengan adanya Taman Pendidikan Al-Qur'an Masjid Al-Fattah dalam penyelenggaraan pendidikan Al-Qur'an ini dapat membantu siswa mengerjakan shalat lima waktu dengan tata cara yang benar.

\section{TPA dalam Menghapal Surat Pendek}

Dari hasil Wawancara dengan Ibu Masmelur mengatakan bahwa saya adalah ibu yang selalu siaga dalam urusan agama. Saya memasukkan anak saya ke dalam TPA tujuannya agar ia menambah ilmu yang didapatkan seperti menghapal hapalan suratsurat pendek. Sehingga ketika kita di rumah telah belajar surat-surat pendek pada saat di TPA ia mengulangnya dan diajarkan dengan baik dan benar maka kita ia pulang saya melihat penambahan hapalan sudah semakin baik dan benar.

Sedangakan Ibu Ike mengatakan terdapat peningkatan hapalan surat-surat pendek seperti surat Al-Fatihah, Al-Ashr, An-Nas, Al-Ikhlas, dan Al-Falaq dan lainlainnya serta hapalan bacaan shalat tarawih masih belum sempurna namun anak saya sudah belajar bahkan ketika dia duduk di bangku TK anak saya sudah diajarkan suratsurat pendek dan lebih difasihkan lagi ketika ia masuk TPA.

Dalam tes kemampuan hapalan surat pendek tingkat dasar di Taman Pendidikan Al-Qur'an (TPA) Masjid Al-Fattah ini tujuannya agar penulis dapat melihat sejauh mana santri yang mengaji TPA Masjid Al-Fattah ini menguasai hapalan surat pendek. 
Dalam hal ini penulis tidak menetapkan harus berapa ayat yang mereka hapal melainkan seperti melakukan wawancara "Berapa ayat yang sudah dikuasai? Dan minta untuk membacakan suratnya". Dari hasil tes tersebut penulis mendapatkan hasil, untuk lebih jelas perhatikan pada tabel berikut.

Tabel. 3

Hasil Hapalan Surat Pendek Tingkat Dasar

\begin{tabular}{|l|l|l|l|}
\hline No & \multicolumn{1}{|c|}{ Nama } & Tahun Masuk & Jumlah Hapalan \\
\hline 1 & Yusuf al-Qomar & 2011 & 14 Surat \\
\hline 2 & Hanniah Nabila & 2011 & 15 Surat \\
\hline 3 & Al-Farid & 2012 & 6 Surat \\
\hline 4 & Ramadhani & 2013 & 12 Surat \\
\hline 5 & M.Prayoga.S. & 2013 & 8 Surat \\
\hline 6 & M. Rian Juliandi & 2014 & 12 Surat \\
\hline 7 & Mahesa Ragil & 2014 & 10 Surat \\
\hline 8 & M. Novan Ade Saputra & 2015 & 12 Surat \\
\hline 9 & M. Bariq Al-Faiz & 2016 & 11 Surat \\
\hline 10 & Nasyirah Tiara Salima & 2016 & 15 Surat \\
\hline
\end{tabular}

\section{Kategori Jumlah Hapalan}

\begin{tabular}{|l|l|}
\hline Jumlah Hapalan & Keterangan \\
\hline $10-15$ Surat & Tingggi $(\mathrm{T})$ \\
\hline $5-10$ Surat & Sedang $(\mathrm{S})$ \\
\hline $5-0$ Surat & Rendah $(\mathrm{R})$ \\
\hline
\end{tabular}

Jika dilihat dari tabel diatas maka dapat dikategorikan santri yang mengaji di Taman Pendidikan Al-Qur'an (TPA) termasuk dalam kategori Tinggi karena hampir rata-rata dari mereka hapal sampai 15 surat untuk tingkat dasar sudah sangat baik. Akan tetapi setelah saya mewawancarai bebeapa dari santri mereka mengatakan bahwa hapalan tersebut tidak hanya didapat di TPA melainkan mereka dapat juga di bangku sekolah sehingga tidak semua yang mereka hapalan itu murni karena hapal dari TPA. Dalam pembelajaraan di TPA Masjid Al-Fattah ini juga mempelajari hapalan surat pendek seperti mereka dibiasakan sebelum memulai pembelajaran mereka membaca surat pendek secara bersama-sama. Sehingga dapat ditarik kesimpulan bahwa dalam hapalan surat pendek di Taman Pendidikan Al-Qur'an ini sudah cukup berperan dalam membantu santri-santri menghapal surat-surat pendek.

Berdasarkan hasil wawancara dan observasi di atas, dapat dipahami bahwa santri dapat menguasai hafalan sejumlah surat pendek. Hal ini dibuktikan dengan sudah terdapat banyak surat-surat pendek yang telah dihapal santri sampai 15 surat. Sehingga dapat dikatakan bahwa dengan adanya Taman Pendidikan Al-Qur'an Masjid Al-Fattah 
dalam penyelenggaraan pendidikan Al-Qur'an ini dapat membantu siswa menguasai hafalan surat-surat pendek.

\section{TPA dalam Mengarahkan Berperilaku Sesuai Tuntutan Islam}

Dari hasil wawancara dengan Ibu Masmelur mengatakan bahwa menurut pengamatan saya anak saya memiliki banyak teman sehingga komunikasi dan sosialnya baik. Ia pandai beradaptasi dengan teman sebayanya dan memiliki sifat tolong menolong. Contohnya adalah ia suka membantu temannya yang sedang membutuhkan pertolongan.

Sedangkan menurut Bapak Mardi mengatakan bahwa terdapat perubahan berprilaku karena anak saya sudah banyak perubahan sosial, seperti cara dia berbicara dengan orang yang lebih tua darinya, dia sekarang lebih bertata krama ketika berbicara dan juga Ibu Santi mengatakan bahwa anaknya sekarang sudah mulai berprilaku lebih baik contohnya biasanya kalo sedang bermain, ketika adzan berkumandang dia langsung pulang. Tidak seperti sebelum masuk TPA masih tetap main sehingga waktu sholatnya sering telat. Sedangkan berdasarkan observasi saya bahwa santri terlihat tertib saat mengikuti penyelenggaraan pendidikan Al-Qur'an. Santri bersama teman sebayanya tampak kompak dan saling tolong-menolong dalam kebaikan.

Berdasarkan hasil wawancara dan observasi di atas, dapat dipahami bahwa siswa memiliki prilaku sosial yang baik sesuai tuntutan Islam. Hal ini dapat dibuktikan dengan adanya sifat tolong menolong di antara santri, santri memiliki tata krama yang baik kepada orang yang lebih tua. Sehingga dapat dikatakan bahwa dengan adanya Taman Pendidikan Al-Qur'an Masjid Al-Fattah dalam penyelenggaraan pendidikan Al-Qur'an ini dapat membantu santri memiliki prilaku sosial yang baik sesuai tuntutan Islam.

\section{TPA dalam Membantu Untuk Dapat Menulis Huruf Arab}

Dari hasil wawancara informan Ibu Masmelur mengatakan bahwa Saya adalah ibu yang selalu melihat dan membimbing anak saya dalam melakukan semua aktivitasnya. Ketika ia sedang mengerjakan atau menulis huruf Arab saya selalu melihat dan jika ada yang salah saya tidak pernah memarahi dan berbicara jika itu salah tetapi saya memberikan pengertian ini tidak salah tetapi belum benar.

Sedangkan Ibu Ike mengatakan bahwa Iya, saya selalu mengeceknya. Walaupun tulisan Arabnya ada yang masih belum benar tugas saya sebagai orang tua memasukakan anak saya ke TPA agar ia belajar menulis huruf Arab yang baik dan benar.

Dalam tes kemampuan menulis arab tingkat dasar terdapat 5 soal diantaranya menulis "Bismillahirrahmanirrahim" dari 10 sampel yang diambil semua santri mampu menulisnya dengan baik dan benar. Menulis "Audzubillah" dari 10 sampel santri yang diambil terdapat 5 yang dalam penulisannya sudah tepat dan benar akan tetapi sisanya hanya mengosongkan jawabannya saja, untuk lebih jelas perhatikan pada tabel. 
Tabel. 4

Hasil Tes menulis Arab Tingkat Dasar

\begin{tabular}{|l|l|l|l|}
\hline No & \multicolumn{1}{|c|}{ Nama } & Tahun Masuk & \multicolumn{1}{c|}{ Nilai } \\
\hline 1 & Yusuf al-Qomar & 2011 & 60 \\
\hline 2 & Hanniah Nabila & 2011 & 95 \\
\hline 3 & Al-Farid & 2012 & 50 \\
\hline 4 & Ramadhani & 2013 & 65 \\
\hline 5 & M.Prayoga.S. & 2013 & 20 \\
\hline 6 & M. Rian Juliandi & 2014 & 80 \\
\hline 7 & Mahesa Ragil & 2014 & 60 \\
\hline 8 & M. Novan Ade Saputra & 2015 & 60 \\
\hline 9 & M. Bariq Al-Faiz & 2016 & 60 \\
\hline 10 & Nasyirah Tiara Salima & 2016 & 75 \\
\hline
\end{tabular}

Peneliti mewawancarai salah satu Ummi yang mengajar di Taman Pendidikan Al-Qur'an (TPA) Masjid Al-Fattah yang bernama Ummi Nidar selaku kepala unit dari Taman Pendidikan Masjid Al-Fattah dalam hal ini ummi Nidar mengatakan bahwa dalam TPA ini diajarkan tulis arab dengan melatih kemampuan menulis mereka setelah santri mengaji satu persatu dengan ummi atau ustadz santri diarahkan untuk menulis di buku tulis mengenai ayat yang mereka baca saat mengaji. Peneliti juga mewawancarai beberapa santri yang jawabannya tidak jauh berbeda dengan apa yang telah dijelaskan ummi Nidar saat mereka sudah mengaji mereka diarahkan untuk menulis apa yang mereka baca dan para santri juga banayak mengakui bahwa mereka rutin belajar menulis arab ini banyak di TPA karena jika di sekolah itu ada pelajaran bahasa arab hanya satu minggu sekali.

Berdasarkan hasil wawancara dan tes, dapat dipahami bahwa siswa dapat menulis huruf Arab dengan baik dan benar. Meskipun terdapat santri yang menulisnya dengan belum sempuna. Akan tetapi kemampuan menulis mereka sudah dapat dikatakan baik karena mereka sering berlatih menulis huruf Arab secara rutin dimana lambat laun kemampuan menulis mereka menjadi lebih baik. Sehingga dapat dikatakan bahwa dengan adanya Taman Pendidikan Al-Qur'an Masjid Al-Fattah dalam penyelenggaraan pendidikan Al-Qur'an ini dapat membantu santri menulis huruf Arab dengan baik dan benar.

\section{Kesimpulan}

Peran TPA dalam penyelenggaraan pendidikan Al-Qur'an di Masjid Al-Fattah Palembang sudah berjalan dengan baik, ada beberapa indikator peran yang mengacu pada tujuan TPA yakni Santri dapat mengagumi dan mencintai Al-Qur'an sebagai bacaan istimewa dan pedoman utama

Berdasarkan hasil wawancara bahwa santri dapat mengagumi dan mencintai Al-Qur'an sebagai bacaan istimewa dan pedoman utama. Hal ini dibuktikan dengan adanya santri 
membaca Al-Qur'an setiap selesai shalat fardhu. Dan mereka menjadikan ayat suci AlQur'an sebagai pedomannya seperti halnya mereka mereka senantiasa membaca ayat Kursi sebagai penjaga dirinya dan surat Al-Ashr sebagai pengingat mereka untuk menjadi anak yang berprilaku disiplin akan waktu. Sehingga dapat dikatakan bahwa Taman Pendidikan Al-Qur'an (TPA) Masjid Al-Fattah dalam penyelenggaran pendidikan Al-Qur'an berperan dengan baik dalam membantu santri mengagumi dan mencintai Al-Qur'an sebagai bacaan istimewa dan pedoman utama. Selanjutnya santri dapat membaca Al-Qur'an dengan benar dan lancar, itu berdasarkan hasil wawancara dan observasi santri dapat membaca Al-Qur'an dengan benar dan lancar. Hal ini dibuktikan dengan terminimalisirnya santri yang membaca Al-Qur'an dengan terteguntegun. Sehingga dapat dikatakan bahwa Taman Pendidikan Al-Qur'an (TPA) Masjid Al-Fattah dalam penyelenggaran pendidikan Al-Qur'an berperan dengan baik dalam membantu santri membaca Al-Qur'an dengan baik dan benar. Santri juga dapat mengerjakan shalat lima waktu dengan tata cara yang benar, yang dibuktikan hasil wawancara dan observasi, santri dapat mengerjakan shalat lima waktu dengan tata cara yang benar. Walaupun masih terdapat santri terdapat gerakan santri yang belum sempurna, akan tetapi berangsur-angsur menjadi lebih baik. Hal ini dibuktikan dengan diadakannya praktik santri mengerjakan shalat satu persatu dengan tata cara yang benar. Sehingga dapat dikatakan bahwa dengan adanya Taman Pendidikan Al-Qur'an Masjid Al-Fattah dalam penyelenggaraan pendidikan Al-Qur'an ini dapat membantu santri mengerjakan shalat lima waktu dengan tata cara yang benar.selain itu juga TPA berperan menjadikan santri dapat menguasai hafalan sejumlah surat pendek, dapat berprilaku sosial yang baik sesuai tuntutan Islam, dan dapat menulis huruf Arab dengan baik dan benar. Sehingga dapat kita pahami bahwa dari 6 pokok tujuan penagajaran TPA sudah bisa dikatakan berperan baik dalam pendidikan Al-Qur'an.

\section{Daftar Pustaka}

Annur, S. (2005). metodelogi Penelitian Pendidikan. Palembang: IAIN Radenfatah Press.

Anwar. (2000). Ulumul Qur'an. Bandung: Pustaka Setia.

Arifin. (2000). Ilmu Pendidikan Islam. Jakarta: Bumi Aksara.

Arifin, H.M. (2003). Ilmu Pendidikan Islam (tinjauan Teoritis dan praktis Berdasarkan Pendekatan Interdisipliner). Jakarta: Bumi Aksara.

Arikunto, S. (2006). Prosedur Penelitian Suatu Pendekatan Praktek. Jakarta: Rineka Cipta.

Depag Sumsel. (2005). Pedoman Kurikulum TPA. Palembang: Depag Sumsel.

Djalali. (2013). Psikologi Pendidikan. Jakarta: Bumi Aksara.

Hasan, F. (1997). Dasar-dasar Pendidikan. Jakarta: Rineka Cipta.

Jalaluddin. (1989). Metode Tunjuk Silang Belajar Al-Qur'an. Jakarta: Kalam Mulia. Moleong, L. (2004). Metodologi Penelitian Kualitatif. Bandung: PT Ramaja Roskarya. Narbuko, C. (2007). Metodologi Penelitian. Jakarta: Bumi Aksara. 
Narbukp, C dan Ahmadi, A. (1997). Metodologi Penelitian (memberikan bekal dan teoritis pada mahasiswa tentang metodelogi penelitian serta diharapkan dapat melaksanakan penelitian dengan langkah-langkah yang benar). Jakarta: Bumi Aksara.

Nuryanis. (2003). Pendidikan Luar Sekolah. Jakarta: Dapertemen Agama RI.

Purnama, Intan. (2013). Kontribusi TPA dalam Upaya meningkatkan Kualitas Baca Tulis Al-Qur'an di TPA Terpadu Bagussalam Desa Tirta Mulya Kecamatan Pulau Rimau Kabupaten Banyuasin" skripsi Fakultas Tarbiyah dan Keguruan. Palembang: IAIN Raden Fatah.

Putra, R. N. (2012). Efektivitas Penyelenggaraan Pembelajaran Taman Pendidikan AlQur'an (TPA) MAsjid Mu'min Lebak Mulyo Kelurahan Pahlawan Palembang" skripsi Fakultas Tarbiyah dan Keguruan. Pelembang: IAIN Raden Fatah.

Sukmadinata, N. S. (2005). Metodologi Penelitian Pendidikan. Bandung: PT. Remaja Rosdakarya.

Susilawati. (2014). Kemampuan Baca Tulis Al-Qur'an Bagi Santri TPA Baitul Hamid PerumAzhar Permai Kabupaten Banyuasin" skripsi dari Fakultas Tarbiyah dan Keguruan. Palembang: IAIN Raden Fatah.

Syarmudin, A. (2006). Panduan Kurikulum dan pengajaran TK/TPA. Palembang: LPPTKA BKPRMI. 